\title{
Broadleaf Weed Control and Crop Safety with Premixed Pyrasulfotole and Bromoxynil in Winter Wheat
}

\author{
Seshadri S. Reddy ${ }^{1 *}$, Phillip W. Stahlman ${ }^{1}$, Patrick W. Geier ${ }^{1}$, Dallas E. Peterson ${ }^{2}$ \\ ${ }^{1}$ Agricultural Research Center, Kansas State University, Hays, USA; ${ }^{2}$ Department of Agronomy, Kansas State University, Manhattan, \\ USA. \\ Email: ${ }^{*}$ ssreddy@ksu.edu
}

Received August $4^{\text {th }}, 2012$; revised September 17 $7^{\text {th }}, 2012$; accepted October $15^{\text {th }}, 2012$

\begin{abstract}
For more than two decades acetolactate synthase (ALS) inhibiting herbicides have been the major weed control tools in winter wheat which resulted in selection of resistant weeds to those herbicides. Premixed pyrasulfotole \& bromoxynil $\left(\right.$ Huskie $^{\circledR}$ ) is a relatively new herbicide registered for use in wheat in 2008. Pyrasulfotole inhibits 4-hydoxyphenylpyruvate dioxygenase (HPPD) enzyme in susceptible plants and is the first significant new mode of action for use in cereals in more than two decades. Field experiments were conducted from 2007 to 2010 at two locations in Kansas, USA to test the efficacy of pyrasulfotole \& bromoxynil for broadleaf weed control and crop safety in winter wheat. Treatments included pyrasulfotole \& bromoxynil alone at $253 \mathrm{~g} \cdot \mathrm{ai} \cdot \mathrm{ha}^{-1}$ and tank mixtures of pyrasulfotole \& bromoxynil at 207 $\mathrm{g} \cdot \mathrm{ai} \cdot \mathrm{ha}^{-1}$ with MCPA at $280 \mathrm{~g} \cdot \mathrm{ai} \cdot \mathrm{ha}^{-1}$, dicamba at $140 \mathrm{~g} \cdot \mathrm{ai} \cdot \mathrm{ha}^{-1}$ or metsulfuron-methyl at $4.2 \mathrm{~g} \cdot \mathrm{ai} \cdot \mathrm{ha}^{-1}$. Herbicides were applied postemergence in fall and spring seasons. Pyrasulfotole \& bromoxynil alone or in combination with tank-mix partners, regardless of application time, controlled flixweed, blue mustard, bushy wallflower and field pennycress $98 \%$ or more. Henbit control was better when pyrasulfotole \& bromoxynil treatments were applied in fall than spring ( $\geq 98 \%$ vs $\geq 67 \%$ ). Pyrasulfotole \& bromoxynil alone applied in spring was not effective on wild buckwheat, but tank mixing with dicamba or metsulfuron-methyl controlled wild buckwheat $84 \%$ or more. Pyrasulfotole \& bromoxynil alone or in tank mixtures caused little $(\leq 7 \%)$ or no injury to wheat and the injury did not influence wheat grain yields. Based on excellent control of broadleaf weeds evaluated, pyrasulfotole \& bromoxynil is an alternative tool to control ALS-inhibitor resistant weeds in winter wheat. Fall season application and tank mixing with other herbicides are desirable for effective broad spectrum weed control.
\end{abstract}

Keywords: Huskie ${ }^{\circledR}$; Henbit; Blue Mustard; Flixweed; Bushy Wallflower; Field Pennycress; Wild Buckwheat; Postemergence; Injury

\section{Introduction}

Wheat (Triticum aestivum L.) is the most important cereal crop in the USA, where it was planted on 23 million ha in 2012 [1]. Most of the wheat grown in the USA is winter wheat (17 million ha). Kansas state ranks first in winter wheat cultivation (4 million ha) in the USA [1]. Winter wheat is not a good competitor with some broadleaf weeds even when wheat emerges before weeds [2]. Common weeds found in winter wheat in the US are blue mustard [Chorispora tenella (Pallas) DC.], henbit (Lamium amplexicaule L.), flixweed [Descurainia sophia (L.) Webb. Ex Prantl], bushy wallflower (Erysimum repandum L.), field pennycress (Thlaspi arvense L.), wild buckwheat (Polygonum convolvulus), shepherd's purse [Capsella bursa-pastoris (L.) Medik.], and pinnate tansymustard [Descurainia pinnata (Walt.) Britt.]. Their

${ }^{*}$ Corresponding author. interference can cause significant yield reduction in winter wheat. Season-long competition of 11,33 , and 98 blue mustard plants $\cdot \mathrm{m}^{-2}$ reduced wheat grain yields by $28 \%, 42 \%$, and $51 \%$, respectively [2]. Conley and Bradley (2005) [3] reported yield reductions of 13 and $38 \%$ because of henbit interference at 82 and 155 plants $\cdot \mathrm{m}^{-2}$, respectively. Northam et al. (1993) [4] also reported wheat grain yield loss of $48 \%$ with 221 henbit plants $\cdot \mathrm{m}^{-2}$. Bushy wallflower at 272 plants $\cdot \mathrm{m}^{-2}$ reduced wheat yields by $25 \%$ [5]. Hence, winter annual broadleaf weed control is very important for successful wheat production.

For more than two decades acetolactate synthase (ALS)-inhibiting herbicides have been primary herbicides used in winter wheat, however continuous usage of those herbicides led to selection of ALS-inhibitor resistant weeds. Currently 126 ALS-inhibitor resistant weed species have been reported worldwide; 45 in the USA [6]. Bushy wallflower and flixweed, two common broadleaf 
weeds in winter wheat, were reported ALS-inhibitor resistant in 2005 and 2006, respectively in Kansas [6-8]. Rotating herbicides with different modes of action can avoid selection for weeds biotypes that are resistant to certain herbicides. Hence, there is a need for herbicides with alternative modes of action to ALS-inhibitor herbicides in wheat.

Pyrasulfotole is a new herbicidal active ingredient belonging to the pyrazoles family of herbicides. Pyrasulfotole inhibits 4-hydoxyphenylpyruvate dioxygenase (HPPD) and blocks the pathway of prenylquinone biosynthesis in plants [9]. This leads to decreased levels of plastoquinone in plant tissue and reduced photosynthetic yield [10]. Indirect inhibition of phytoene desaturase as a consequence of blocked plastoquinone biosynthesis subsequently leads to a decrease in carotenoids [11] and consequently prevents stabilization of the photosynthetic apparatus so that chlorophyll molecules are destroyed by excessive light energy. Inhibition of HPPD also prevents biosynthesis of tocopherols that leads to reduced vitamin E synthesis, which means loss of protection against oxidative stress and against photo inactivation of the photosynthesis apparatus. The whole process will result in typical bleaching symptoms in the newly developing leaves during the first week after application. These bleaching symptoms progress toward necrosis and susceptible plants generally die within two to three weeks after treatment. Pyrasulfotale is the first significant compound with a new mode of action for broadleaf weed control in wheat, barley and triticale in more than 20 years.

The prepacked mixture of pyrasulfotole \& bromoxynil
(Huskie $^{\circledR}$, Bayer CropScience, P.O. Box 12014, 2 T.W. Alexander Drive, Research Triangle Park, North Carolina 27709, USA) received US registration for use in wheat in 2008. Bromoxynil belongs to the nitrile group and inhibits photosynthesis at photosystem II in susceptible plants. The premix also contains the safener mefenpyr-diethyl. The recommended dose of pyrasulfotole \& bromoxynil is 207 to $282 \mathrm{~g} \cdot \mathrm{ai} \cdot \mathrm{ha}^{-1}$ and recommended stage of application in wheat is first leaf to flag leaf emergence. The herbicide label recommends tank mixing pyrasulfotole \& bromoxynil with dicamba, MCPA, metsulfuron-methyl or 2,4-D for broad spectrum weed control. Currently not much information on use of pyrasulfotole \& bromoxynil in winter wheat is available. The objectives of the study were 1) to evaluate premixed pyrasulfotole \& bromoxynil with and without other herbicides for efficacy and safety in winter wheat and 2) to determine the optimum time for its application.

\section{Material and Methods}

Field experiments were conducted for two years near Hays (2007-2009) and for three years near Manhattan (2007-2010) in Kansas in the central USA. Soil characteristics of the sites are given in Table 1. Experimental design was a randomized complete block with four treatment replications. The pyrasulfotole \& bromoxynil premix was tested alone or in tank mix combinations with other herbicides applied postemergence (POST) at two timings. The rate of pyrasulfotole \& bromoxynil used was $253 \mathrm{~g} \cdot \mathrm{ai} \cdot \mathrm{ha}^{-1}$ without other herbicides and $207 \mathrm{~g} \cdot \mathrm{ai} \cdot \mathrm{ha}^{-1}$ when tank mixed. Tank mixture partners tested were MCPA ester at $280 \mathrm{~g} \cdot \mathrm{ai} \cdot \mathrm{ha}^{-1}$, dicamba at $140 \mathrm{~g} \cdot \mathrm{ai} \cdot \mathrm{ha}^{-1}$,

Table 1. Soil characteristics and planting and spraying information, Hays and Manhattan, KS, 2007-2010.

\begin{tabular}{|c|c|c|c|c|c|}
\hline & \multicolumn{2}{|c|}{ Hays, KS } & \multicolumn{3}{|c|}{ Manhattan, KS } \\
\hline & $2007-2008$ & 2008-2009 & $2007-2008$ & 2008-2009 & $2009-2010$ \\
\hline Soil type & Roxbury silt loam & Crete silty clay loam & Reading silt loam & Reading silt loam & Reading silt loam \\
\hline Soil pH & 7.7 & 6.3 & 5.7 & 5.7 & 5.7 \\
\hline Organic matter $(\%)$ & 2.5 & 2 & 2.9 & 2.9 & 2.9 \\
\hline Wheat cultivar & Danby & KS08HW35-1 & Overley & Overley & Fuller \\
\hline Seed rate $\left(\mathrm{kg} \cdot \mathrm{ha}^{-1}\right)$ & 73 & 63 & 78 & 78 & 78 \\
\hline Planting date & $10 / 02 / 2007$ & $10 / 01 / 2008$ & $10 / 11 / 2007$ & $10 / 08 / 2008$ & $10 / 19 / 2009$ \\
\hline Plot size & $2.5 \times 6.7$ & $2.5 \times 6.7$ & $1.9 \times 6$ & $1.9 \times 6$ & $1.9 \times 6$ \\
\hline Fall-POST spray date & $11 / 04 / 2007$ & $11 / 07 / 2008$ & $11 / 27 / 2007$ & $11 / 25 / 2008$ & $12 / 04 / 2009$ \\
\hline Spring-Post spray date & $03 / 13 / 2008$ & $03 / 16 / 2009$ & $03 / 28 / 2008$ & $03 / 17 / 2009$ & $03 / 29 / 2010$ \\
\hline
\end{tabular}


and metsulfuron-methyl at $4.2 \mathrm{~g} \cdot \mathrm{ai} \cdot \mathrm{ha}^{-1}$. A commercial standard of premixed triasulfuron \& dicamba at 165 $\mathrm{g} \cdot \mathrm{ai} \cdot \mathrm{ha}^{-1}$ and a non-treated control were also included in the study. Non-ionic surfactant at $0.5 \% \mathrm{v} / \mathrm{v}$ and $28 \%$ urea ammonium nitrate at $4.7 \mathrm{~L} \cdot \mathrm{ha}^{-1}$ were included with all herbicide treatments. Treatments were applied postemergence to winter wheat at two timings, i.e. fall postemergence (fall-POST) and spring postemergence (springPOST). Herbicides were applied broadcast using backpack or tractor-mounted plot sprayers, calibrated to deliver 121 to $139 \mathrm{~L} \cdot \mathrm{ha}^{-1}$ at 172 to $207 \mathrm{kPa}$. Henbit, flixweed and blue mustard were predominate weed species at Hays, and henbit, flixweed, bushy wallflower, field pennycress and wild buckwheat were predominate at Manhattan. Wheat variety, seeding rate, plot size, row spacing, planting and application dates are presented in Table 1. Generally, wheat was $5-10 \mathrm{~cm}$ tall with $1-2$ tillers at fall-POST application and $7.5-15 \mathrm{~cm}$ tall with 2 - 5 tillers at spring-POST application. Likewise, except wild buckwheat, weeds were $1-2.5 \mathrm{~cm}$ tall at fall-POST and $2.5-7.5 \mathrm{~cm}$ at spring-POST application. Wild buckwheat had not emerged by the time of fall-POST applications at Manhattan; they emerged in spring and were at cotyledon to 4 leaf stage when spring-POST treatments were applied.

Weed control and crop injury were rated based on composite visual estimations of density reduction, growth inhibition, and foliar injury on a scale of 0 (no effect) to 100 (plant death). Henbit, flixweed and blue mustard control ratings were determined 195 to 224 days after planting (DAP) at Hays. Similarly, henbit, flixweed, bushy wallflower and field pennycress control ratings were determined 190 to 206 DAP at Manhattan. Wild buckwheat control was determined 236 to 258 DAP at Manhattan. Wheat injury was visually assessed 2 weeks after fall-POST and spring-POST applications at each location. Grain yield was determined by harvesting the six center rows of each plot with a plot combine and adjusting seed weight to $12.5 \%$ moisture content. Yields were not determined at Manhattan in 2008 due to hail damage. Data were analyzed using the general linear model procedure of SAS (Statistical Analysis Systems Institute, Cary, NC, USA) and means were separated at the 5\% significance level using Fisher's protected LSD. Percent weed control and wheat injury were arcsine transformed before analysis. The control treatment was omitted from weed control and crop injury analyses, but included in the analysis of wheat grain yield. Because there was significant year by location by treatment interaction for henbit and flixweed control data are presented year wise for each location (Table 2). Year by treatment interactions were significant for blue mustard, bushy wallflower and field pennycress and hence data are presented year wise for respective locations. Wild buck- wheat control ratings at Manhattan were pooled over years 2007-2008 and 2008-2009 because year by treatment interaction was non-significant. Wheat injury rating were pooled over years and presented separately for each site because site by treatment interactions were significant.

\section{Results and Discussion}

\subsection{Weed Control}

\subsubsection{Henbit}

In 2007-2008, at Hays, fall-POST application of all herbicides controlled henbit better than spring-POST treatments (Table 3). Complete control of henbit was achieved with all fall-POST treatments. Among spring-POST treatments henbit control was lowest with tank mixture of pyrasulfotole \& bromoxynil + metsulfuron-methyl $(86 \%)$ and premixed triasulfuron \& dicamba (84\%). Henbit control was essentially complete, regardless of herbicide or application timing at Hays in 2008-2009. At Manhattan, all pyrasulfotole \& bromoxynil treatments applied fall-POST controlled henbit $\geq 98 \%$, but control varied significantly among spring-POST treatments (67\% $100 \%$ ). Lowest henbit control was observed with triasulfuron \& dicamba applied either fall-POST or springPOST compared to pyrasulfotole \& bromoxynil treatments, however fall-POST treatment was much better than spring-POST treatment (88\% - 95\% vs 53\% - 63\%). These results indicate that pyrasulfotole \& bromoxynil with or without tank mixtures controlled henbit better than commercial standard triasulfuron \& dicamba. However, fall applications of pyrasulfotole \& bromoxynil were better than spring applications. This could be due to the fact that henbit was smaller in size in fall $(1-2.5 \mathrm{~cm})$ compared to spring $(2.5-7.5 \mathrm{~cm})$. Contrary to our results, Martin et al. (2008) [12] reported complete control of henbit with pyrasulfotole \& bromoxynil alone or in combination with dicamba regardless of application timing (fall or spring). In our experiment it was also noticed that, in two instances, pyrasulfotole \& bromoxynil + metsulfuron-methyl applied spring-POST controlled henbit less compared to pyrasulfotole \& bromoxynil alone or in combination with MCPA. Generally, ALS-inhibiting herbicides (triasulfuron and metsulfuron-methyl) control henbit better when applied in fall than spring.

\subsubsection{Flixweed, Blue Mustard, Bushy Wallflower and Field Pennycress}

The premix of pyrasulfotole \& bromoxynil alone or in combination with MCPA, dicamba or metsulfuronmethyl, across locations, controlled flixweed and blue mustard, $98 \%$ or more regardless of application timing (Table 4). Data on flixweed at Hays in 2008-2009 and at Manhattan in 2007-2008 and 2009-2010, and on blue mustard at Hays in 2007-2008 are not presented here 
Table 2. Analysis of variance (ANOVA) results for weed control and crop injury ${ }^{\mathrm{a}, \mathrm{b}}$.

\begin{tabular}{lcccccccc}
\hline \multicolumn{1}{c}{ Source } & Henbit & Flixweed & Blue mustard & Bushy wallflower & Field pennycress & Wild buckwheat & Injury-F & Injury-S \\
\hline Year & $* * *$ & $* *$ & $*$ & $* *$ & $* * *$ & NS & $* * *$ & NS \\
Location & $* * *$ & NS & - & - & - & - & $* * *$ & $* * *$ \\
Year $\times$ location & $* * *$ & $* * *$ & - & - & - & - & $* * *$ & $* * *$ \\
Treatment & $* * *$ & $* * *$ & $* * *$ & $* * *$ & $* * *$ & $* * *$ & $* *$ & $* * *$ \\
Year $\times$ treatment & $* * *$ & $* * *$ & $* * *$ & $* * *$ & $* * *$ & NS & NS & $* *$ \\
Location $\times$ treatment & $* * *$ & $* * *$ & - & - & - & - & $* *$ & $* * *$ \\
Year $\times$ location $\times$ treatment & $* * *$ & $* * *$ & - & - & - & - & $* *$ & NS \\
\hline
\end{tabular}

${ }^{a}$ Abbreviation: NS, not significant; injury-F, injury due to fall treatments; injury-S, injury due to spring treatments; ${ }^{b}$ Results of ANOVA based upon arcsine-transformed data; $* \mathrm{P}=0.05-0.01 ; * * \mathrm{P}=0.01-0.001 ; * * * \mathrm{P}=0.001-0.0001$.

Table 3. Henbit control with POST application of premixed pyrasulfotole \& bromoxynil and its tank mixtures, Hays and Manhattan, $\mathbf{K S}^{\mathbf{a}}$.

\begin{tabular}{|c|c|c|c|c|c|c|c|}
\hline \multirow{3}{*}{ Treatments $^{\mathrm{b}}$} & \multirow{3}{*}{$\begin{array}{c}\text { Time of } \\
\text { application }\end{array}$} & \multirow{2}{*}{ Rate } & \multicolumn{2}{|c|}{ Hays } & \multicolumn{3}{|c|}{ Manhattan } \\
\hline & & & $2007-2008$ & 2008-2009 & $2007-2008$ & 2008-2009 & $2009-2010$ \\
\hline & & $\mathrm{g} \cdot \mathrm{ha}^{-1}$ & --- & - & $--\%$ & & \\
\hline Pyrasulfotole $^{c}$ & Fall & 253 & 100 & 99 & 98 & 98 & 100 \\
\hline Pyrasulfotole + MCPA & Fall & $207+280$ & 100 & 100 & 99 & 100 & 100 \\
\hline Pyrasulfotole + metsulfuron-methyl & Fall & $207+4.2$ & 100 & 100 & 100 & 100 & 100 \\
\hline Triasulfuron \& dicamba & Fall & 165 & 100 & 100 & 88 & 92 & 95 \\
\hline Pyrasulfotole & Spring & 253 & 94 & 100 & 99 & 80 & 97 \\
\hline Pyrasulfotole + MCPA & Spring & $207+280$ & 95 & 99 & 99 & 82 & 100 \\
\hline Pyrasulfotole + metsulfuron-methyl & Spring & $207+4.2$ & 86 & 100 & 93 & 67 & 97 \\
\hline Triasulfuron \& dicamba & Spring & 165 & 84 & 100 & 63 & 53 & 53 \\
\hline $\operatorname{LSD}(0.05)$ & & & 4 & NS & 4 & 10 & 5 \\
\hline
\end{tabular}

${ }^{\mathrm{a}}$ Abbreviations: NS, non-significant; ${ }^{\mathrm{b}}$ All herbicide treatments include non-ionic surfactant at $0.5 \% \mathrm{v} / \mathrm{v}$ and $28 \%$ urea ammonium nitrate at $4.7 \mathrm{~L} \cdot$ ha ${ }^{-1}$; ${ }^{\mathrm{c}} \mathrm{Pyra}-$ sulfotole has bromoxynil as premix partner.

because weed control was almost complete and treatment differences were not significant. These results are consistent with reports of $98 \%$ - 99\% control of flixweed and $96 \%$ - 99\% control of blue mustard in Oregon with spring-applied pyrasulfotole \& bromoxynil [13]. In our study, bushy wallflower and field pennycress were controlled $90 \%$ or more, regardless of application time, and there were no significant differences among treatments (data not shown). The commercial standard triasulfuron \& dicamba controlled all four weeds completely when applied fall-POST, but control was occasionally lower than pyrasulfotole \& bromoxynil treatments when applied in spring. Across locations, triasulfuron \& dicamba applied spring-POST controlled flixweed by $83 \%-100 \%$, blue mustard $89 \%-100 \%$, bushy wallflower $90 \%$ $100 \%$ and field pennycress $90 \%-100 \%$.

\subsubsection{Wild Buckwheat}

At Manhattan, wild buckwheat emerged late after fallPOST application and plants were small at the time of spring-POST application. Spring-applied pyrasulfotole \& bromoxynil alone or in combination with MCPA provided poor wild buckwheat control $(3 \%$ and $12 \%$, respectively) (Table 4). However, when pyrasulfotole \& bromoxynil was tank mixed with dicamba or metsulfuronmethyl control of wild buckwheat was $84 \%$ or more. Spring applied triasulfuron \& dicamba controlled wild buckwheat $94 \%$. Even though wild buckwheat had not emerged at the time of fall-POST application, pyrasulfotole \& bromoxynil + metsulfuron-methyl and triasulfuron \& dicamba applied in fall controlled wild buckwheat $73 \%$ and $87 \%$, respectively. This might be due to residual activity of metsulfuron and triasulfuron in the 
soil. Metsulfuron-methyl and triasulfuron can persist in the soil up 4 and 12 weeks, respectively [14]. These results indicated that pyrasulfotole \& bromoxynil premix alone applied in spring has very little effect on wild buckwheat.

\subsection{Crop Injury and Grain Yields}

At Hays, averaged over years, pyrasulfotole \& bromoxynil alone or in combination with MCPA or dicamba or metsulfuron-methyl applied in fall or spring caused 1 to $4 \%$ wheat injury, but the injury was not significant among treatments (Table 5). At Manhattan, no injury was obesrved with pyrasulfotole \& bromoxynil treatments when applied in fall, but up to $7 \%$ injury was observed when applied in spring. Triasulfuron \& dicamba caused $0 \%$ to $6 \%$ injury. However, injury symptoms disappeared within 3 to 4 weeks and did not influence wheat grain yields (data not shown). In a study conducted at Oregon, no wheat injury was observed with pyrasulfotole \& bromoxynil applied in spring at $282 \mathrm{~g} \cdot \mathrm{ai} \cdot \mathrm{ha}^{-1}$ [13]. This tolerance in wheat might be due to faster metabolic degradation of the herbicide inside the plant. Wheat grain

Table 4. Fixweed, blue mustard and wild buckwheat control with POST application of premixed pyrasulfotole \& bromoxynil and its tank mixtures.

\begin{tabular}{|c|c|c|c|c|c|c|}
\hline \multirow{4}{*}{ Treatments $^{\mathrm{a}}$} & \multirow{4}{*}{$\begin{array}{c}\text { Time of } \\
\text { application }\end{array}$} & \multirow{3}{*}{ Rate } & \multicolumn{2}{|c|}{ Flixweed } & \multirow{2}{*}{$\begin{array}{c}\text { Blue mustard } \\
\text { Hays }\end{array}$} & \multirow{2}{*}{$\begin{array}{c}\text { Wild buckwheat } \\
\text { Manhattan }\end{array}$} \\
\hline & & & Hays & Manhattan & & \\
\hline & & & $2007-2008$ & 2008-2009 & $2007-2008$ & Pooled ${ }^{\text {c\&d }}$ \\
\hline & & $\mathrm{g} \cdot \mathrm{ha}^{-1}$ & \multicolumn{4}{|c|}{ 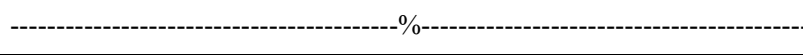 } \\
\hline Pyrasulfotole $^{b}$ & Fall & 253 & 100 & 100 & 99 & 0 \\
\hline Pyrasulfotole + MCPA & Fall & $207+280$ & 100 & 100 & 99 & 0 \\
\hline Pyrasulfotole + dicamba & Fall & $207+140$ & 100 & 100 & 98 & 0 \\
\hline Pyrasulfotole + metsulfuron-methyl & Fall & $207+4.2$ & 100 & 100 & 100 & 73 \\
\hline Triasulfuron \& dicamba & Fall & 165 & 100 & 100 & 100 & 87 \\
\hline Pyrasulfotole & Spring & 253 & 100 & 100 & 99 & 3 \\
\hline Pyrasulfotole + MCPA & Spring & $207+280$ & 100 & 100 & 100 & 12 \\
\hline Pyrasulfotole + dicamba & Spring & $207+140$ & 100 & 100 & 100 & 84 \\
\hline Pyrasulfotole + metsulfuron-methyl & Spring & $207+4.2$ & 100 & 100 & 100 & 92 \\
\hline Triasulfuron \& dicamba & Spring & 165 & 96 & 83 & 89 & 94 \\
\hline $\operatorname{LSD}(0.05)$ & & & 1 & 3 & 2 & 12 \\
\hline
\end{tabular}

${ }^{\mathrm{a}}$ All herbicide treatments include non-ionic surfactant at $0.5 \% \mathrm{v} / \mathrm{v}$ and $28 \%$ urea ammonium nitrate at $4.7 \mathrm{~L} \cdot \mathrm{ha}^{-1}$; ${ }^{\mathrm{b}} \mathrm{Pyrasulfotole}$ has bromoxynil as premix partner; ${ }^{\mathrm{c}}$ Data pooled over years 2007-2008 and 2008-2009; ${ }^{\mathrm{d}}$ Wild buckwheat did not emerge at the time of fall applications.

Table 5. Wheat injury caused by premixed pyrasulfotole \& bromoxynil and its tank mixtures applied in fall and spring seasons, Hays and Manhattan, $\mathrm{KS}^{\mathrm{a}}$.

\begin{tabular}{|c|c|c|c|c|c|}
\hline \multirow{3}{*}{ Treatments $^{\mathrm{b}}$} & \multirow{2}{*}{ Rate } & \multicolumn{2}{|c|}{14 DAFT } & \multicolumn{2}{|c|}{14 DAST } \\
\hline & & Hays & Manhattan & Hays & Manhattan \\
\hline & $g \cdot h a^{-1}$ & 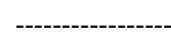 & 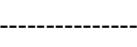 & --- & --- \\
\hline Pyrasulfotole $^{c}$ & 253 & 2 & 0 & 2 & 0 \\
\hline Pyrasulfotole $+\mathrm{MCPA}$ & $207+280$ & 1 & 0 & 1 & 0 \\
\hline Pyrasulfotole + dicamba & $207+140$ & 4 & 0 & 1 & 7 \\
\hline Pyrasulfotole + metsulfuron-methyl & $207+4.2$ & 3 & 0 & 2 & 1 \\
\hline Triasulfuron $\&$ dicamba & 165 & 4 & 0 & 0 & 6 \\
\hline $\operatorname{LSD}(0.05)$ & & NS & NS & NS & 2 \\
\hline
\end{tabular}

${ }^{\mathrm{a}}$ Abbreviations: DAFT, days after fall treatments; DAST, days after spring treatments; NS, non-significant; ${ }^{\mathrm{b}}$ All herbicide treatments include non-ionic surfactant at $0.5 \% \mathrm{v} / \mathrm{v}$ and $28 \%$ urea ammonium nitrate at $4.7 \mathrm{~L} \cdot \mathrm{ha}^{-1}$. ${ }^{\mathrm{c}}$ Pyrasulfotole has bromoxynil as premix partner. 
yields were not influenced by any treatment compared to untreated control (data not shown). High densities of winter annual broadleaf species often reduce wheat yields, sometimes dramatically, but controlling low to medium density weed populations does not always result in higher grain yields $[15,16]$. Analysis of 25 experiments conducted over a several year period in Oklahoma found that effective herbicidal control of weeds did not increase wheat yields most of the time; yield increased when bushy wallflower density was as much as 830 plants $\cdot \mathrm{m}^{-2}$ [16]. Still good weed control is necessary in winter wheat to prevent multiplication of weed density in future.

\section{Conclusion}

Premixed pyrasulfotole \& bromoxynil alone at 253 $\mathrm{g} \cdot \mathrm{ai} \cdot \mathrm{ha}^{-1}$ or pyrasulfotole \& bromoxynil at $207 \mathrm{~g} \cdot \mathrm{ai} \cdot \mathrm{ha}^{-1}$ in combination with MCPA, dicamba or metsulfuronmethyl applied postemergence either in fall or spring controlled blue mustard, flixweed, bushy wallflower and field pennycress $98 \%$ or more. Henbit control with pyrasulfotole \& bromoxynil treatments was much better when they were applied in fall than spring ( $\geq 98 \%$ vs $\geq 67 \%$ ). Pyrasulfotole \& bromoxynil applied alone in spring was not effective on wild buckwheat, but tank mixing with dicamba or metsulfuron-methyl controlled wild buckwheat $84 \%$ or more. Hence, tank mixing pyrasulfotole \& bromoxynil with other herbicides is desirable for broad spectrum of weed control. Minor ( $\leq 7 \%)$ or no crop injury was noticed with pyrasulfotole \& bromoxynil treatments regardless of application time. It can be concluded that the new herbicide pyrasulfotole $\&$ bromoxynil can safely be used in wheat for broadleaf weed control in spring or fall season, but fall application is desirable for better weed control. With a new and unique mode of action, premix of pyrasulfotole \& bromoxynil is an effective alternative herbicide for wheat growers to combat weeds resistant to ALS-inhibiting herbicides.

\section{Acknowledgements}

The authors thank Bayer CropScience for their financial support to this project. Contribution number 13-174-J from the Kansas Agricultural Experiment Station.

\section{REFERENCES}

[1] USDA-NASS (US Department of Agriculture-National Agricultural Statistics Service), "Acreage-June 2012," USDA-NASS, Washington, 2012.

http://usda01.library.cornell.edu/usda/current/Acre/Acre-0 6-29-2012.pdf

[2] D. G. Swan, "Competition of Blue Mustard with Winter Wheat," Weed Science, Vol. 19, No. 4, 1971, pp. 340-342.

[3] S. P. Conley and K. W. Bradley, "Wheat (Triticum aesti- vum) Yield Response to Henbit (Lamium amplexicaule) Interference and Simulated Winterkill," Weed Technology, Vol. 19, No. 4, 2005, pp. 902-906. doi:10.1614/WT-04-252R.1

[4] F. E. Northam, P. W. Stahlman and M. Abd El-Hamid, "Broadleaf weed Control in Winter Wheat," Western Society of Weed Science Research Progress Report, Vol. 111, 1993, pp. 173-175.

[5] D. E. Peterson, "Weed Management," Wheat Production Handbook, Kansas State University Cooperative Extension Service, Manhattan, 1997, C-529.

[6] I. Heap, "The International Survey of Herbicide Resistant Weeds," 2012. www.weedscience.com.

[7] D. E. Peterson, K. Al-Khatib and R. Roberts, "ALS Resistance in a Biotype of Bushy Wallflower," Proceedings of Western Society of Weed Science, Vol. 59, 2006, p. 42.

[8] D. E. Peterson, K. Al-Khatib, C. R. Thompson and T. M. Maxwell, "Confirmation of ALS-Resistant Flixweed in Kansas," Proceedings of Western Society of Weed Science, Vol. 62, 2009, p. 30.

[9] V. A. Andreas, "New HPPD-Inhibitors-A Proven Mode of Action as a New Hope to Solve Current Weed Problems," Outlooks on Pest Management, Vol. 20, No. 1, 2009, pp. 27-30. doi:10.1564/20feb09

[10] A. Trebst, B. Depka, J. Jager and W. Oettmeier, "Reversal of the Inhibition of Photosynthesis by Herbicides Affecting Hydroxyphenylpyruvate Dioxygenase by Plastoquinone and Tocopheryl Derivatives in Chlamydomonas reinhardii," Pest Management Science, Vol. 60, 2004, pp. 669-674. doi:10.1002/ps.847

[11] A. Schulz, O. Oswald, P. Beyer and H. Kleinig, "SC-0051, a 2-Benzoyl-cyclohexane-1,3-dione Bleaching Herbicide, Is a Potent Inhibitor of the Enzyme p-Hydroxyphenylpyruvate Dioxygenase," FEBS Letters, Vol. 318, 1993, pp. 162-166. doi:10.1016/0014-5793(93)80013-K

[12] J. Martin, C. Tutt and D. Call, "Herbicide Evaluation of Henbit Control in No-Till Wheat," 2008. http://www.ca.uky.edu/ukrec/RR\%202007-08/RR07-08pg 40.pdf

[13] J. Felix and J. Ishida, "Huskie Herbicide Performance Relative to Commercial Standard Herbicides in Winter Wheat," Malheur Experiment Station Annual Report 2008, Oregon State University, Ontario, 2009, pp. 151-152. http://ir.library.oregonstate.edu/xmlui/bitstream/handle/19 57/13358/MalheurExperimentStationAnnualReport2008.p df? sequence $=1$

[14] C. R. Thompson, D. E. Peterson, W. H. Fick, P.W. Stahlman and R. E. Wolf, "Chemical Weed Control for Field Crops, Pastures, Rangeland, and Non-Cropland," Report of Progress 1063, Kansas State University, Manhattan, 2012.

[15] T. A. Baughman and T. F. Peeper, "Red Horn Poppy (Glaucium corniculatum) Control in Winter Wheat," Weed Technology, Vol. 6, No. 4, 1992, pp. 909-912.

[16] R. C. Scott, T. F. Peeper and J. A. Koscelny, "Winter Wheat (Triticum aestivum) Yield Response to Winter Annual Broadleaf Weed Control," Weed Technology, Vol. 9, No. 3, 1995, pp. 594-598. 